\title{
Study In Silico Compounds in 96\% Ethanol Extract of Chrysanthemum cinerariifolium (Trev.) Leaves Towards Alfa Estrogen Receptors
}

\author{
Roihatul Mutiah*, Yen Yen Ari Indrawijaya, Dwi Puspita \\ Department of Pharmacy, Faculty of Medical and Health Sciences, Maulana Malik Ibrahim State Islamic University of \\ Malang, Indonesia
}

\begin{abstract}
Chrysanthemum cinerariifolium (Trev.) is a plant that has potential as an anticancer. This study aimed to predict the inhibitor of estrogen alpha and toxicity of compounds in $96 \%$ ethanol extract of $C$. cinerariifolium leaves in silico. Prediction of the activity of metabolic profiling compounds produced by UPLC QToF MS/MS ethanol extract $96 \%$ of $C$. cinerariifolium leaves towards alpha estrogen receptors (ER-a) (5W9C) was carried out using Molegro Virtual Docker. The docking results showed that the compound (2-Methyl1,4-piperazinediyl) bis-[(3,4,5-trimethoxyphenyl)-methanone and Azoxystrobin have good activity compared to Tamoxifen, because these compounds have a lower Rerank Score. The activity of the test compound is also shown by the bonding of active amino acids (Arg 394, Asp351, Glu 353, and Val 533). As for the toxicity class based on Globally Harmonized System (GHS) and Lethal Dose $50\left(\mathrm{LD}_{50}\right)$ values, the ten docking compounds had a relatively low toxicity.
\end{abstract}

Keywords: C. cinerariifolium, breast cancer, alpha estrogen, cytotoxic activity, toxicity

\section{INTRODUCTION}

Breast cancer is a cancer that develops from breast tissue. It is the most common invasive cancer in women. Signs of breast cancer include a lump in the breast, a change in breast shape, dimpling of the skin, nipple discharge, or a red scaly patch of skin (Kabel and Baali, 2015). During 2014 in Indonesia, breast cancer ranked first among women with 48,998, above cervical cancer (20,928 events), and colorectal cancer (11,787 events) (WHO, 2014). The development of breast cancer cells occurs by several factors: estrogen and estrogen receptors. High estrogen levels and excessive expression of alpha estrogen receptors (ER- $\alpha$ ) can trigger the development of breast cancer cells (Hayashi, 2003). Alpha estrogen receptors are called molecular targets that suppress proliferation of breast cancer cells. ER- $\alpha$ are used as the main marker to identify the presence of tumors in breast tissue (Setiawati, et $a l ., 2014)$. Beta estrogen receptors (ER- $\beta$ ) has the same structural domains as ER- $\alpha$, but its function is not exactly the same as ER- $\alpha$. The role of ER- $\beta$ in breast cancer remains elusive, and ER- $\beta$ is currently not used in the diagnosis or treatment of breast cancer patients (Leygue and Murphy, 2013).

The hormonal drug used in people with breast cancer is Tamoxifen. This drug works as an estrogen receptor antagonist in the breast.

Submitted: June 26, 2020

Revised: August 14, 2020

Accepted: August 18, 2020

*Corresponding author: roiha@farmasi.uin-malang.ac.id 
However, Tamoxifen also has side effects, including thromboembolism, non-alcoholic fatty liver disease, and increased proliferation of endometrial carcinoma (Dermawan, et al., 2019). It is necessary to find new treatments to reduce these side effects, such as using medicinal plants (Katno and Pramono, 2017).

One of the plants that can be usedempirically as an anticancer is $C$. cinerariifolium (Alviana, et al., 2016; Listiyana, et al., 2019). Previous studies have reported that terpenoids and flavonoids include dominant compounds in the Chrysanthemum plant (Ukiya, et al., 2002). Flavonoid compounds can be called SERMs, which can enter cells and bind with ER- $\alpha$ and form complex bonds, then bind to estrogen response element (ERE) and activate an NCoR co-repressor protein and suppress cancer cell replication so that its proliferation can be controlled (Bryant, 2002; Girault, et al., 2006). Listiyana, et al. (2019) identified the metabolite profile of $96 \%$ ethanol extract of $C$. cinerariifolium leaves using UPLC-QToF-MS/MS, so in this research prediction of the compound content of $C$. cinerariifolium leaves which has potential as breast anticancer with in silico method.

The in silico approach with molecular modeling on the development of computational chemistry is currently utilized to develop new drugs. This computational chemical technique can accelerate the selection of isolated and synthesized compounds by identifying and optimizing guiding compounds in the drug discovery process. In this study, we performed the prediction inhibitor of ER- $\alpha$ and toxicity of the compounds in $96 \%$ ethanol extract of $C$. cinerariifolium leaves towards ER- $\alpha$.

\section{MATERIALS AND METHODS}

\section{Materials}

The device used was a laptop with specifications: Intel® InsideTM CORETM i3 processor, 4GB RAM, and 600GB hard disk and Windows TM Seven Ultimate operating system software. Programs used include Chem-Bio Ultra 12.0, pkCSM online tool, Protox II online tool, and Molegro Virtual Docker 6.0. While the material was a three-dimensional estrogen alpha structure (PDB: 5W9C) and the structure of the test compound that passed the screening.

\section{Methods \\ Compound Screening}

Two-dimensional molecular structure of the compound produced by metabolite profiling on ethanol leaves extracted $96 \%$ of $C$. cinerariifolium with Chem-Bio Ultra 12.0 and copied by the SMILES code in SwissADME application, then selected the compounds according to parameters (not penetrate the brain barrier, P-GP non-substrate, and based on the criteria of the Lipinski Rules of Five $(\mathrm{MW} \leq 500 \mathrm{~g} / \mathrm{mol}, \log P$ value $\leq 5, \mathrm{HBD} \leq 5$, $\mathrm{HBA} \leq 10, \mathrm{TPSA} \leq 140 \AA$ and Torsion $\leq 10)$ ).

\section{Ligand-Protein Docking Sample Preparation}

ER- $\alpha$ (PDB:5W9C) was download at PDB (https://www.rcsb.org/). The test compound the energy minimization of the compound that passed was tested by pressing MMFF94 in the Avogadro application, then stored in the form of mol2 $\{$ SYBYL2 $(*$. Mol2) $\}$.

\section{Docking Molecular}

The detection of cavities by a selected cavity had an RMSD value $\leq 2$. Then, put the $3 \mathrm{D}$ structure of compounds that passed screening into the selected cavity, then docking of the compound to the receptor by using the Molegro Virtual Docker version 6.0. To measure the strength of drug binding to the receptor, the Rerank Score can be seen.

\section{Toxicity Prediction}

The prediction of toxicity parameters of each compound uses the SMILES code. The code entered in the pkCSM application (http://biosig. unimelb.edu.au/pkcsm/prediction) to predict 
Lethal Dose $50\left(\mathrm{LD}_{50}\right)$ values, Ames toxicity, and Hepatotoxicity. Meanwhile, to predict the toxicity of compounds $\mathrm{LD}_{50}$ based on the Globally Harmonized System (GHS) Protox online tool is used (http://tox.charite.de/protox_II/).

\section{RESULTS}

\section{Compound Screening}

The initial step in this research is screening compounds using the SwissADME program. In this research, the samples used were 35 compounds resulting from metabolite profiling UPLC-QToFMS/MS ethanol extract $96 \%$ of $C$. cinerariifolium leaves (Table 1) (Listiyana, et al., 2019). The results of screening compounds through Boiled-Eggs can be observed in Figure 1.

Based on these images of 35 compounds screened using the SwissADME application (A), only 10 compounds that passed with parameters not penetrate the blood brain barrier, P-gp nonsubstrate, and based on the criteria of the Five Lipinski Rules (B). Furthermore, ten compounds which pass screening will be molecular docking to ER- $\alpha$ (PDB: 5W9C).

\section{Ligand-Protein Docking}

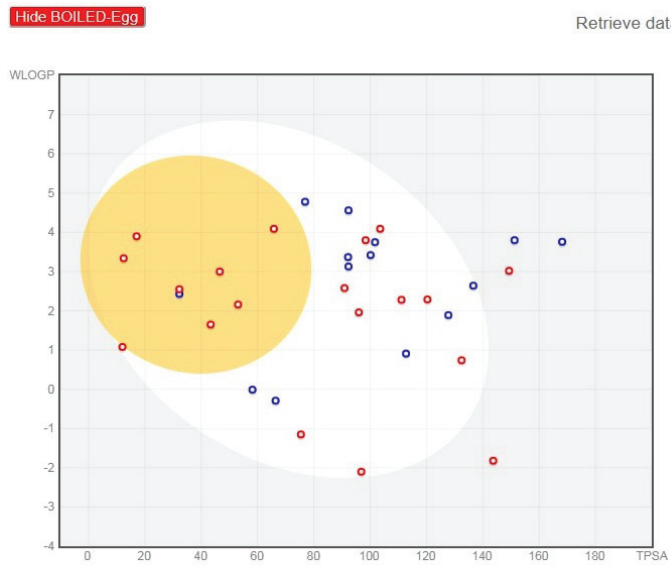

A
The next step is the docking molecular. This step aimed to discover the interaction of compounds that pass screening with the target receptor (Ekins, et al., 2007). The receptor used in this study is the alpha estrogen receptor (PDB: 5W9C). The RMSD value of this receptor is 1.0354 of cavity 7 with ligand A, 0.9348 of cavity 8 with ligand $\mathrm{B}, 0.8501$ of cavity 6 with ligand $C$, and 1.0224 of cavity 5 with ligand D.

The smaller RMSD value obtained indicates that the predicted pose ligand is getting better because it is getting closer to native ligand conformation (Susanti, et al., 2018). So that the hole (cavity) used is cavity 6 with ligand native C. The next step is docking simulation with a scoring parameter where the parameter is a score that can measure the strength of the drug bond with the receptor. The docking results obtained in this research shown in Figure 2, Figure 3, and Table 2.

Based on visualization results on hydrogen interactions, native ligands bind two key residues, namely Glu 353 (C) and Arg 394 (C). Compounds that bind to amino acids are the same as native ligands in hydrogen interactions, including (2R) -2-Amino3-Trisulfanyl-propanal, Azoxystrobin, Genistein, Isorhamnetin, Kaempferol, and Isoleucine-Alanine

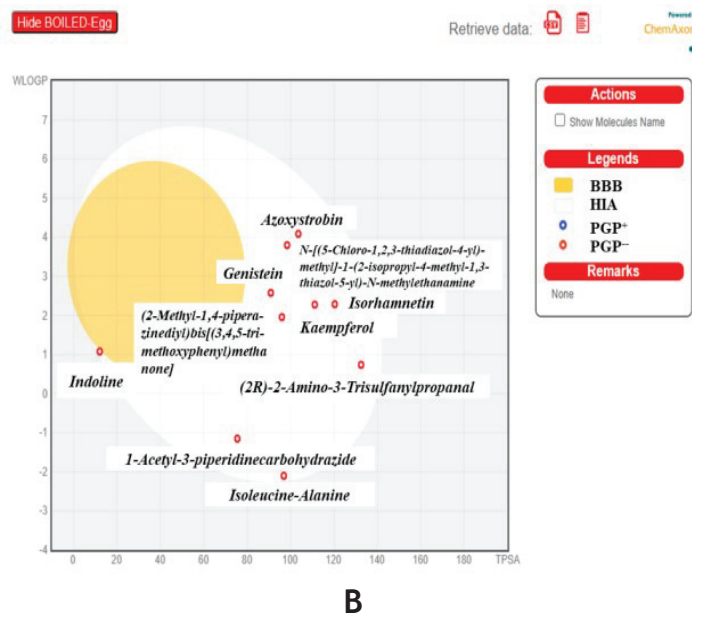

Figure 1. The results of screening compounds with SwissADME (A) and the compounds that passed screening with SWissADME (B) 
Indonesian Journal of Cancer Chemoprevention, October 2020

ISSN: 2088-0197

e-ISSN: $2355-8989$

Table 1. Compounds resulting from metabolite profilling UPLC-QTOF-MS/MS ethanol extract $96 \%$ leaves of

C. culinerifolium (Listiyana, et al., 2019):

\begin{tabular}{|c|c|c|c|}
\hline \%Area & Calculated (M/Z) & Formula & Name of Compounds \\
\hline 0.0837 & 150.0277 & $\mathrm{C}_{3} \mathrm{H}_{6} \mathrm{~N}_{2} \mathrm{O}_{5}$ & Urea ethanedioate \\
\hline 0.0398 & 292.0565 & $\mathrm{C}_{11} \mathrm{H}_{12} \mathrm{~N}_{6} \mathrm{~S}_{2}$ & $\begin{array}{l}\text { 9-Methyl-5- (methylsulfanyl)-8,9,10,11-tetrahydropyrido- } \\
{\left[4^{\prime}, 3^{\prime}: 4,5\right] \text { thieno }[3,2-\text {-e]tetrazolo }[1,5-c] \text { pyrimidine }}\end{array}$ \\
\hline 1.0781 & 119.0735 & $\mathrm{C}_{9} \mathrm{H}_{9} \mathrm{~N}$ & Indoline \\
\hline 0.1100 & 202.1317 & $\mathrm{C}_{9} \mathrm{H}_{18} \mathrm{~N}_{2} \mathrm{O}_{3}$ & Isoleucyl-alanine dipeptida \\
\hline 0.7538 & 187.0633 & $\mathrm{C}_{\| \prime} \mathrm{H}_{9} \mathrm{NO}_{2}$ & Indoleacrylic acid \\
\hline 0.0526 & 185.1164 & $\mathrm{C}_{8} \mathrm{H}_{15} \mathrm{~N}_{3} \mathrm{O}_{2}$ & I-Acetyl-3-Piperidinecarbohydrazide \\
\hline 0.2818 & 216.0899 & $\mathrm{C}_{n} \mathrm{H}_{12} \mathrm{~N}_{2} \mathrm{O}_{2}$ & $\begin{array}{l}\text { 3',4'-Dihydro-l'H,2H,5H-spiro[imidazolidine-4,2'- naphthalene]-2,5- } \\
\text { dione }\end{array}$ \\
\hline 0.3684 & 243.1471 & $\mathrm{C}_{12} \mathrm{H}_{21} \mathrm{NO}_{4}$ & Tiglylcarnitine \\
\hline 0.3261 & 439.2471 & $\mathrm{C}_{25} \mathrm{H}_{33} \mathrm{~N}_{3} \mathrm{O}_{4}$ & $\mathrm{~N}$-lsobutyl- $\mathrm{N}^{2}-\{2-[(4-$ methoxybenzoy $\mid)$ amino $]$ benzoyl\}-isoleucinamide \\
\hline 0.1707 & 462.0798 & $\mathrm{C}_{1} \mathrm{H}_{23} \mathrm{~N}_{4} \mathrm{~S}_{2} \mathrm{Cl}$ & $\begin{array}{l}\text { 4-Chloro-2-(\{4-[(2,6-dimethyl-4-morpholinyl)sulfony?-1-piperazinyl]- } \\
\text { sulfonyl)benzonitrile }\end{array}$ \\
\hline 0.1249 & 578.1636 & $\mathrm{C}_{27} \mathrm{H}_{30} \mathrm{O}_{14}$ & Kaempferitrin \\
\hline 0.5915 & 446.0862 & $\mathrm{C}_{n} \mathrm{H}_{1} \mathrm{~N}_{4} \mathrm{O}_{3}$ & $\begin{array}{l}\mathrm{N}-[(1,3-D i o x o-1,3-d \text { thydro- } 2 \mathrm{H} \text {-isoindol-2-yl)methyl]- 3,5-dinitro- } \mathrm{N} \text { - } \\
\text { phenylbenzamide }\end{array}$ \\
\hline 0.0720 & 527.1922 & $\mathrm{C}_{25} \mathrm{H}_{34} \mathrm{NO} \mathrm{Cll}_{5}$ & $\begin{array}{l}\text { I-(Nitrooxy)-2- propanyl(5Z)-7-\{(IR,2R,3R,5S)-2-[(IE,3R)-4-(3- } \\
\text { chloro-phenoxy)-3-hydroxy- I-buten-I-y]-3,5-dihydroxy-cydopentyl\}- } \\
\text { 5- heptenoate }\end{array}$ \\
\hline 0.1556 & 459.2257 & $\mathrm{C}_{25} \mathrm{H}_{33} \mathrm{NO}_{7}$ & $\begin{array}{l}\text { 2-Methoxyethyl 2,7,7-trimethyl-5-oxo-4-(3,4,5-trimethoxyphenyl)- } \\
\text { 1,45,6,7,8-hexahydro-3-quinolinecarboxylate }\end{array}$ \\
\hline 0.2245 & 286.0477 & $\mathrm{C}_{15} \mathrm{H}_{10} \mathrm{O}_{6}$ & Kaempferol \\
\hline 0.1001 & 316.0583 & $\mathrm{C}_{16} \mathrm{H}_{12} \mathrm{O}_{7}$ & Isorhamnetin \\
\hline 1.7179 & 270.0528 & $\mathrm{C}_{15} \mathrm{H}_{100} \mathrm{O}_{5}$ & Genistein \\
\hline 1.8113 & 330.0740 & $\mathrm{C}_{13} \mathrm{H}_{19} \mathrm{~N}_{4} \mathrm{~S}_{2} \mathrm{Cl}$ & $\begin{array}{l}\mathrm{N}-[(5-C h l o r o-1,2,3-\text { thiadiazol-4-y }) \text { methyl] }-1-(2-\text { isopropyl-4-methyl- } \\
\text { I,3-thiazol-5-yl)-N-methylethanamine }\end{array}$ \\
\hline 0.0101 & 488.2159 & $\mathrm{C}_{25} \mathrm{H}_{32} \mathrm{~N}_{2} \mathrm{O}_{3}$ & (2-Methyl-1,4-piperazinediyl)bis[[3,4,5-trimethoxyphenyl)-methanone] \\
\hline 0.0150 & 309.2304 & $\mathrm{C}_{18} \mathrm{H}_{31} \mathrm{NO}_{3}$ & $\begin{array}{l}\text { N.N-Diisobutyl-4,7,7-trimethyl-3-oxo-2- oxabicyclo[22 I] } \\
\text { carboxamide }\end{array}$ \\
\hline 0.2336 & 471.2257 & $\mathrm{C}_{28} \mathrm{H}_{33} \mathrm{NO}_{7}$ & $\begin{array}{l}\text { 2-Methoxyethyl 4-(4- acetoxy-3-ethoxyphenyl)- 2,7,7-trimethyl-5-oxo- } \\
\text { I,4,5,6,7,8-hexahydro-3-Quinolinecarboxylate }\end{array}$ \\
\hline 0.0365 & 344.0905 & $\mathrm{C}_{19} \mathrm{H}_{20} \mathrm{O}_{2} \mathrm{~S}_{2}$ & 2-(7,8-Dimethyl-1,5-dihydro-2,4-benzodithiepin-3-y)phenyl-Acetate \\
\hline 0.0225 & 521.2414 & $\mathrm{C}_{30} \mathrm{H}_{35} \mathrm{NO}_{7}$ & $\begin{array}{l}\text { 2-Phenoxyethyl 2,7,7-trimethyl-5-oxo-4-(2,3,4-trimethoxyphenyl)- } \\
\text { I,4,5,6,7,8-hexalydro-3-quinolinecarboxylate }\end{array}$ \\
\hline 0.4170 & 229.1467 & $\mathrm{C}_{15} \mathrm{H}_{19} \mathrm{NO}$ & Pronetalol \\
\hline 0.0098 & 403.1168 & $\mathrm{C}_{22} \mathrm{H}_{17} \mathrm{~N}_{3} \mathrm{O}_{5}$ & Azoxystrobin \\
\hline 0.1533 & 218.1671 & $\mathrm{C}_{15} \mathrm{H}_{22} \mathrm{O}$ & (+)-Nootkatone \\
\hline 0.5352 & 267.1623 & $\mathrm{C}_{18} \mathrm{H}_{21} \mathrm{NO}$ & Azacyclonol \\
\hline 3.2354 & 269.1780 & $\mathrm{C}_{18} \mathrm{H}_{23} \mathrm{NO}$ & Orphenadrine \\
\hline 0.5113 & 387.0986 & $\mathrm{C}_{19} \mathrm{H}_{18} \mathrm{~N}_{3} \mathrm{O}_{4} \mathrm{Cl}$ & Pyraclostrobin \\
\hline 0.1104 & 519.3322 & $\mathrm{C}_{23} \mathrm{H}_{41} \mathrm{~N}_{7} \mathrm{O}_{2}$ & $\begin{array}{l}\text { 3-[(4-Cyclohexyl-I- piperaziny })(1-\text { cyclohexyl- IH-tetrazol-5-yl)- } \\
\text { methyl]-6-ethoxy-2(IH)-quinolinone }\end{array}$ \\
\hline 0.6823 & 602.5274 & $\mathrm{C}_{38} \mathrm{H}_{79} \mathrm{O}_{4}$ & 3,4-Bis(hexadecyloxy) benzoic acid \\
\hline 14.7994 & 608.2635 & $\mathrm{C}_{35} \mathrm{H}_{36} \mathrm{~N}_{4} \mathrm{O}_{6}$ & $\begin{array}{l}\text { 3,3', } 3^{\prime \prime}-(3,8,13,17-\text { Tetramethyl-12-vinyl-2, }, 18 \text {-porphyrintriyl)- } \\
\text { tripropanoic acid }\end{array}$ \\
\hline 3.3663 & 594.2842 & $\mathrm{C}_{33} \mathrm{H}_{36} \mathrm{~N}_{4} \mathrm{O}_{5}$ & Pheophorbide A \\
\hline 0.0030 & 181.9771 & $\mathrm{C}_{8} \mathrm{H}_{3} \mathrm{O}_{3} \mathrm{Cl}$ & 5-Chloro-2-benzofuran-1,3-dione \\
\hline 0.0010 & 168.9690 & $\mathrm{C}_{3} \mathrm{H}_{7} \mathrm{NOS}_{3}$ & (2R)-2-Amino-3-Trisulfanylpropanal \\
\hline
\end{tabular}


dipeptide. As for the comparative drug (Tamoxifen) only binds to Asp 351 (C) and does not bind the amino acids Glu 353 (C) and Arg 394 (C). In the study of Dermawan, et al. (2019), Tamoxifen forms hydrogen bonds with amino acid residues Glu 353 and Arg 394. The hydroxyl group of the phenol in 4-hydroxytamoxifen establishes a tridentate hydrogen bond interaction with the carboxylate of Glu 353, a molecule of water and the guanidinium of Arg 394. The phenolic group is referred to the motor of binding for estrogens and antiestrogen to the ER (Médina, et al. 2004).

Active amino acids in steric bonds found in native ligands are Asp 351 (C), Val 533 (C), Glu 353 (C), and Arg 394 (C). The compounds that bind amino acids together with native ligands in steric interactions include: (2R) -2-Amino-3Trisulfanylpropanal, Azoxystrobin, Genistein, Isorhamnetin, (2-Methyl-1,4-piperazinediyl) bis [(3, 4, 5-tri-methoxyphenyl) methanone], 1-Acetyl -3-piperidine carbohydrazide, Kaempferol, and Isoleucine Alanine dipeptide. For electrostatic interactions in native ligands and comparative drugs, only Asp 351 (C) while in the ligands tested none bonded the amino acid Asp 351 (C).

\section{Prediction of Toxicity}

The next step is to predict the toxicity of the compounds that pass the screening. Toxicity prediction results using $\mathrm{LD}_{50}$ parameters, AMES mutagenic test, Hepatotoxicity, skin sensitization, and toxicity class shown in Table 3.

Based on Table 4, the compounds are classified as toxicity class $5\left(2000<\mathrm{LD}_{50} \leq 5000\right)$, which, according to GHS classification, are classified as drugs with low toxicity. In the classification of toxic levels in the GHS of classification and labeling of chemicals, it is mentioned that above doses of $2000 \mathrm{mg} / \mathrm{kgBW}$ are included in the category of low toxicity and there are no safety symbols or warning signs in labeling that need to be included (Makiyah and Tresnayanti, 2017). According to Hodge and Sterner (1949) states that toxicity class 4 in GHS means that the compound has relatively low toxicity. Compounds classified as Class 3, where the risk of toxicity is higher than Class 4 and 5 .

\section{DISCUSSION}

This study aimed to predict the inhibitor of estrogen alpha and toxicity through in silico test of compounds in $96 \%$ ethanol extract of $C$.
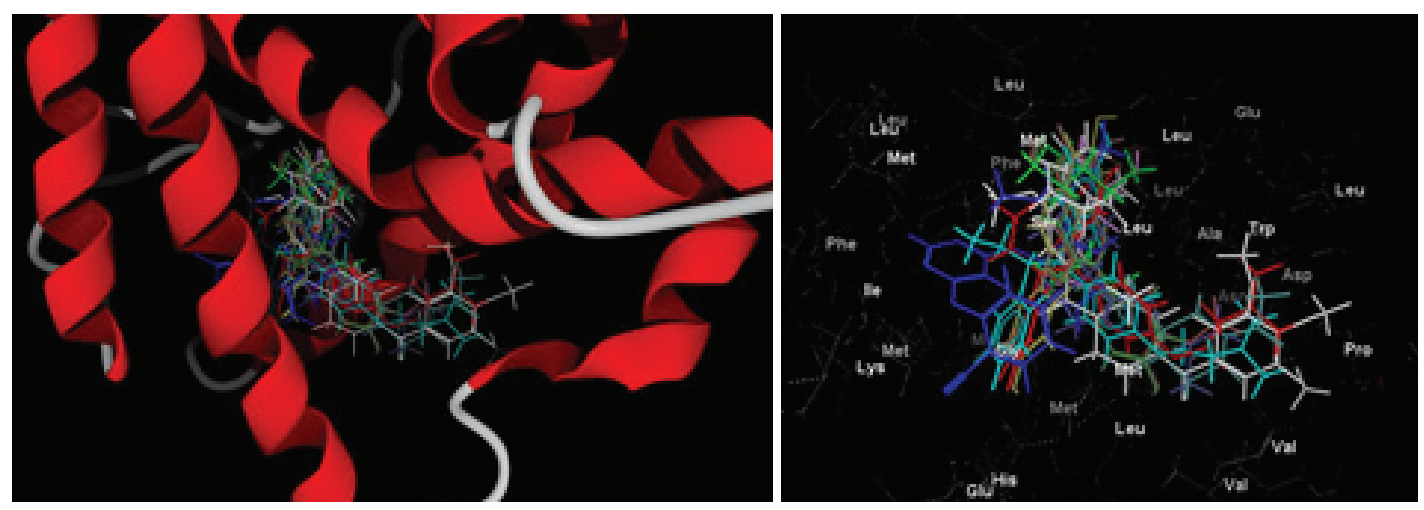

Figure 2. The two-dimensional interactions are shown between the test compounds against the ER-a chain $C$ with native ligands and comperative drug. 

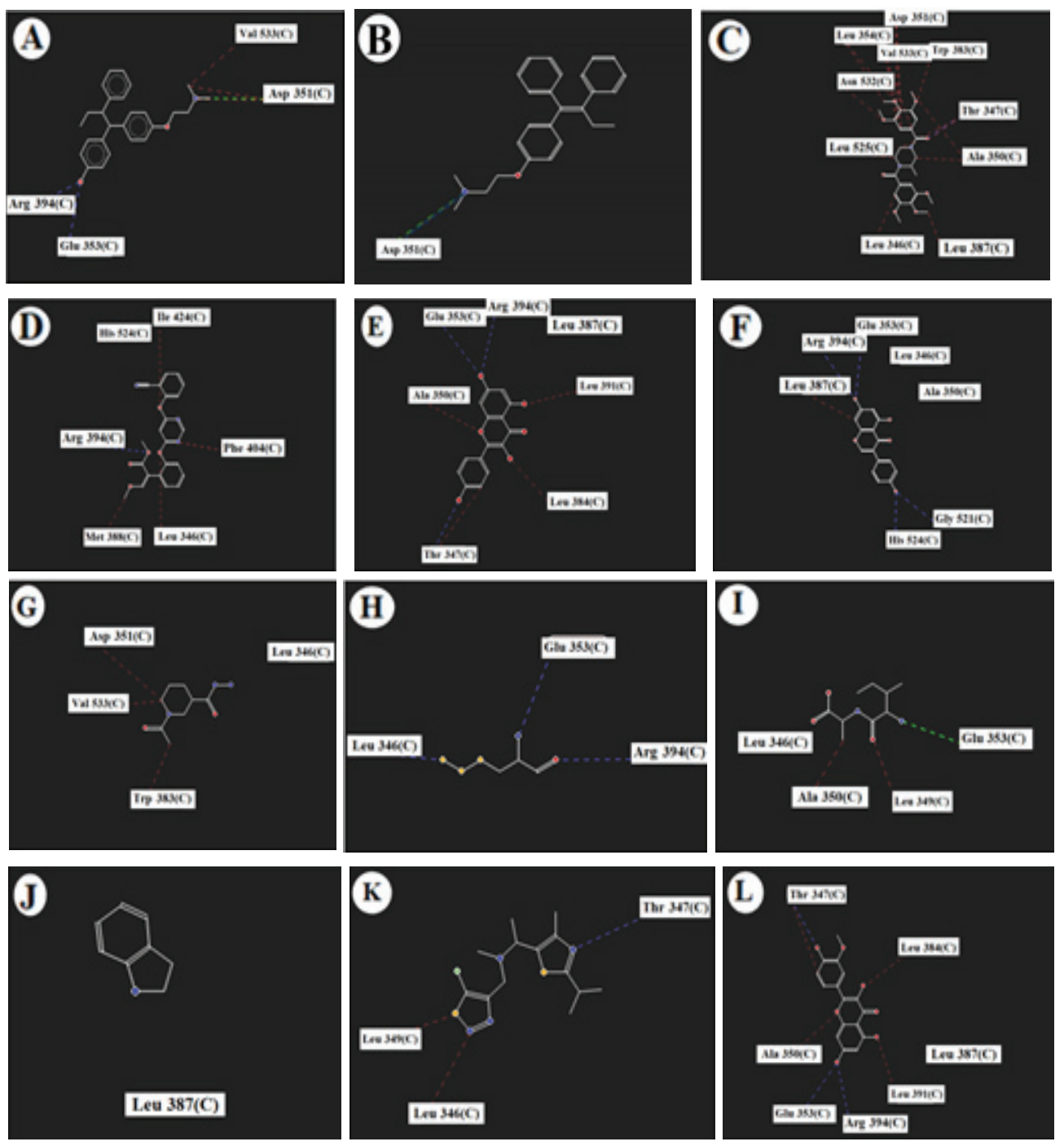

Figure 3. Two dimensions form of hydrogen and steric bonds between (A) native ligand (B) Tamoxifen (C) 2-Methyl-1,4-piperazinediyl) bis [(3,4,5-trimethoxyphenyl)-methanone] (D) Azoxyatrobin (E) Kaempferol (F) Genistein (G) 1-Acetyl-3-piperidinecarbohydrazide (H) (2R) -2-Amino-3-Trisulfanylpropanal (I) Isoleucine-Alanine dipeptide (J) Indoline (K) N- [(5-Chloro -1,2,3-thiadiazol-4-yl) methyl] -1(2-isopropyl-4-methyl-1,3-thiazol-5-yl) -N-methylethanamine and (L) Isrhamnetin with ER-a (5W9C); blue lines as hydrogen bonds and red lines as steric bonds.

cinerariifolium leaves. The preliminary test of docking molecular in silico in this study was to screen compounds (Adnyani, et al., 2019). Based on Figure 1 shows that of the 35 compounds, ten compounds passed screening with parameters not penetrating the blood-brain barrier, P-GP nonsubstrate, and based on the criteria of the Five Lipinski Rules. To avoid the toxicity and MDR in the body, in this research chose a compound that does not penetrating the blood-brain barrier and P-GP non-substrate.

Another critical parameter in drug development is the physicochemical prediction of a compound, where the prediction based on the Five Lipinski Rules so that the drug has good permeability and good oral bioavailability (Hardjono, 2013). According to these rules, drug compounds must have a molecular weight of 
Table 2. Interactions of Ligands with Amino Acids and Rerank Scores

\begin{tabular}{|c|c|c|c|c|}
\hline \multirow[b]{2}{*}{ Compounds } & \multicolumn{3}{|c|}{ Amino Acid } & \multirow[t]{2}{*}{ Rerank Score } \\
\hline & Hydrogen Interaction S & teric Interaction & $\begin{array}{l}\text { Electrostatic } \\
\text { Interaction }\end{array}$ & \\
\hline Indoline & - & Leu 387(C) & - & -46.9828 \\
\hline Isoleucine-Alanine dipeptide & Glu 353(C) & $\begin{array}{l}\text { Ala 350(C), Leu 349(C), Glu } \\
353(C) \text {, Leu } 346(C)\end{array}$ & Glu 353(C) & -72.0238 \\
\hline $\begin{array}{l}\text { I-Acetyl-3-piperidine } \\
\text { carbohydrazide }\end{array}$ & - & $\begin{array}{l}\text { Val 533(C), Asp 35I(C), Trp } \\
\text { 383(C), Leu 346(C) }\end{array}$ & - & -59.6584 \\
\hline Kaempferol & $\begin{array}{c}\text { Glu 353(C), Arg 394(C), } \\
\text { Thr 347(C) }\end{array}$ & $\begin{array}{l}\text { Leu 39l(C), Leu 384(C), Thr } \\
\text { 347(C), Ala 350(C), Arg 394(C), } \\
\text { Glu 353(C), Leu 387(C) }\end{array}$ & - & -77.3413 \\
\hline Isorhamnetin & $\begin{array}{c}\text { Thr 347(C), Glu 353(C), } \\
\text { Arg 394(C) }\end{array}$ & $\begin{array}{l}\text { Thr 347(C), Leu 384(C), Leu } \\
\text { 39I(C), Ala 350(C), Leu 387(C), } \\
\text { Glu 353(C), Arg 394(C) }\end{array}$ & - & -88.6277 \\
\hline Genistein & $\begin{array}{l}\text { Glu 353(C), Arg 394(C), } \\
\text { Gly 52I(C), His 524(C) }\end{array}$ & $\begin{array}{l}\text { Leu 387(C), Arg 394(C), Glu } \\
\text { 353(C), Ala 350(C), Leu 346(C), } \\
\text { Gly 521(C), His 524(C) }\end{array}$ & - & -74.1667 \\
\hline $\begin{array}{l}\mathrm{N}-[(5-C h l o r o-1,2,3 \text {-thiadiazol- } \\
\text { 4-yl)methyl]-I-(2-isopropyl-4- } \\
\text { methyl-I,3-thiazol-5-yl)-N- } \\
\text { methylethanamine }\end{array}$ & Thr 347(C) & $\begin{array}{l}\text { Leu } 349(C) \text {, Leu 346(C), Thr } \\
347(C)\end{array}$ & - & -91.8557 \\
\hline $\begin{array}{l}\text { (2-Methyl-I,4- } \\
\text { piperazinediyl)bis[(3,4,5- } \\
\text { trimethoxyphenyI)methanone }]\end{array}$ & Thr 347(C) & $\begin{array}{l}\text { Asp 35I(C), Leu 354(C), Val } \\
533(C) \text {, Trp 383(C), Ala 350(C), } \\
\text { Thr 347(C), Leu 525(C), Leu } \\
\text { 346(C), Asn 532(C), Leu 387(C) }\end{array}$ & - & -107.4830 \\
\hline Azoxystrobin & Arg 394(C) & $\begin{array}{l}\text { Ile 424(C), Phe 404(C), Leu 346(C), } \\
\text { Met 388(C), Arg 394(C), His } \\
\text { 524(C) }\end{array}$ & - & -96.8537 \\
\hline $\begin{array}{l}\text { (2R)-2-Amino-3- } \\
\text { Trisulfanylpropanal }\end{array}$ & $\begin{array}{c}\text { Leu 346(C), Arg 394(C), } \\
\text { Glu 353(C) }\end{array}$ & $\begin{array}{l}\text { Leu 346(C), Glu 353(C), Arg } \\
394(C)\end{array}$ & - & -50.0824 \\
\hline Tamoxifen & Asp 35I (C) & Asp 35I(C) & Asp $351(C)$ & -94.7420 \\
\hline $\begin{array}{l}\text { 4-Hydroxytamoxifen } \\
\text { (Ligand Native) }\end{array}$ & Glu 353(C), Arg 394(C) & $\begin{array}{l}\text { Asp 35I(C), Val 533(C), Glu } \\
353(C), \operatorname{Arg} 394(C)\end{array}$ & Asp 35I(C) & -112.3033 \\
\hline
\end{tabular}

less than $500 \mathrm{~g} / \mathrm{mol}$, a $\log P$ value of less than 5 , Hydrogen Bond Donors (HBD) value of not more than 5, and Hydrogen Bond Acceptors (HBA) value of not more than 10. Research has further added two more criteria to make the oral bioavailability of a drug better. These criteria included: Topological Polar Surface Area (TPSA) with a value of $\leq 140 \AA$ and rotating hydrogen bond (Torsion) with a value of $\leq 10$ (Chagas, et al., 2018).

In ordered to validate the scoring function, before redocking molecules for selecting prospective hits, we preparation into $5 \mathrm{~W} 9 \mathrm{C}$ protein structure in MVD. There are 4 chain of ER- $\alpha$ protein in 5W9C were each charged with its ligand. Subsequently, we compared the conformation and position with the bound ligand conformation measured regarding the rootmean square deviation (RMSD).

Based on the results in table 2, compounds Azoxystrobin and (2-Methyl-1,4-piperazinediyl) bis [(3,4,5-trimethoxy-phenyl) -methanone] show a smaller Rerank Score compared to Tamoxifen as a comparison drug, thus making the level of affinity for ER- $\alpha$ higher because of the lower energy required to bind to the receptors. This compound can be a candidate for ER- $\alpha$ positive breast cancer therapy. The smaller Rerank Score or bond energy indicates more stable bonds and results in increased activity. Bond energy stated the amount of energy needed to carry out interactions between ligands and receptors (Thomsen, et al., 2006; Kusumaningrum, et al., 2014). 
Indonesian Journal of Cancer Chemoprevention, October 2020

Table 3. Prediction of toxicity using Protox II online and pkCSM online tool

\begin{tabular}{|c|c|c|c|c|c|}
\hline \multirow{2}{*}{ Compounds } & \multicolumn{5}{|c|}{ Toxicity } \\
\hline & A* & B* & C*** & D*** & $\mathbf{E}^{* * *}$ \\
\hline Indoline & 1250 & 4 & No & No & Yes \\
\hline Isoleucine-Alanine dipeptide & 3750 & 5 & No & No & No \\
\hline I-Acetyl-3-piperidine carbohydrazide & 650 & 4 & Yes & Yes & No \\
\hline Kaempferol & 3919 & 5 & No & No & No \\
\hline Isorhamnetin & 5000 & 5 & No & No & No \\
\hline Genistein & 2500 & 5 & No & No & No \\
\hline $\begin{array}{l}\mathrm{N}-[(5-C h l o r o-1,2,3 \text {-thiadiazol-4-yl)methyl]- I-(2- } \\
\text { isopropyl-4-methyl-1,3-thiazol-5-yl)- }\end{array}$ & 200 & 3 & No & Yes & No \\
\hline Nmethylethanamine & & & & & \\
\hline $\begin{array}{l}\text { (2-Methyl-I,4-piperazinediyl)bis[ }[(3,4,5- \\
\text { trimethoxyphenyl)-methanone }]\end{array}$ & 1000 & 4 & No & No & No \\
\hline Azoxystrobin & 500 & 4 & No & Yes & No \\
\hline (2R)-2-Amino-3-Trisulfanylpropanal & 156 & 3 & No & No & Yes \\
\hline Tamoxifen & 1190 & 4 & Yes & No & No \\
\hline
\end{tabular}

Note: $\mathrm{LD}_{50}(\mathrm{mg} / \mathrm{kg})(\mathrm{A})$, Toxicity Class (B), AMES Mutagenic Test (C), Hepatoxicity (D), and Skin Sensitivity (E). *Using Protox II Online Tool, **Using pkCSM Online Tool.

The similarity of the amino acid residue Arg 394 involved in the ER- $\alpha$ receptor binding process will cause compounds to inhibit receptor activity by competitive inhibitors (Figure 3). It was reported in a previous study that molecular interactions in Arg 394 were assumed to be the bonds responsible for the computational chemical antagonistic activity which has potential pharmacological activities as inhibitors of ER- $\alpha$ breast cancer (Zein, et al., 2016). The role of Glutamic Acid (Glu) in hydrogen bonds has been described as having a role in inhibiting tumor development by suppressing the process of angiogenesis (Baek, et al., 2017). The amino acid Asp-351 in the ER- $\alpha$ receptor ligand binding domain plays an important role in regulating activities such as alpha estrogen inhibition from the SERM complex (Jordan, et al., 2015).

The interaction between ligand with amino acid Arg 394, Glu 353, and Asp 351 makes the ligand and ER- $\alpha$ interaction have lower bond energy or Rerank Score. So that the native ligand (4-hydroxytamoxifen) has the lowest Rerank Score than the other ligands. Shiau (1998) states that the interaction of 4-hydroxytamoxifen with ER- $\alpha$ causes changes in the $12^{\text {th }}$ helical conformation which is a coactivator region, this conformational change causes the coactivator binding site to close so that the next signal transduction process does not occurand the cell proliferation process is inhibited.

\section{CONCLUSION}

The compound in $96 \%$ ethanol extract of C. cinerariifolium leaves predicted in silico to inhibiting ER- $\alpha$ (PDB: 5W9C) as indicated by the interaction of active amino acids (Arg 394, Asp 351, Glu 353, and Val 533). There are two compounds have lower rerank score than the comparative drug (Tamoxifen). Test compounds also predicted to have relatively low toxicity.

\section{ACKNOWLEDGEMENT}

Thanks to Prof. Dr. apt. Siswandono, M.S., which has licensed the Molegro Virtual Docker application version 6.0.

\section{REFERENCES}

Adnyani, K.D., Lestari, L.W.E., Prabowo, H., Siaka, P.A.I.A. and Laksmiani, N.P.L., 2019, Aktivitas dari Kuersetin Sebagai Agen Pencerah Kulit Secara In silico[Activity of Quercetin as a Skin Lightening Agent by In silico], Journal of Chemistry, 13(2), 207-212.

Alviana, N., Sidharta, B.R. and Martini, T., 2016, Uji EfektivitasAntibakteri EkstrakEtanol Daun Krisan (Chrysanthemum morifolium Syn. Dendrathema 
grandiflora) Terhadap Staphylococcus aureus dan Escherichia coli [Antibacterial Effectiveness Test of Ethanol Extract of Chrysanthemum Leaves (Chrysanthemum morifolium Syn. Dendrathema grandiflora) on Staphylococcus aureus and Escherichia coli], Yogyakarta: Atma Jaya University.

Baek, Y.Y., Lee, D.K., Kim, J., Kim, J.H., Park, W., et al., 2017, Arg-Leu-Tyr-Glu Tetrapeptide Inhibits Tumor Progression By Suppressing Angiogenesis and Vascular Permeability Via Vegf Receptor-2 Antagonism, Oncotarget, 8(7), 11763-11777.

Bryant, H., 2002, Selective Estrogen Receptor Modulators, Rev Endocr Metab Dis, 3(2), 31-4.

Chagas, C.M., Moss, S. and Alisaraiea, L., 2018, Drug metabolites and their effects on the development of adverse reactions: Revisiting Lipinski's Rule of Five, International Journal of Pharmaceutics, 549, 133-149.

Dermawan, D., Sumirtanurdin, R. and Dewantisari, D., 2019, Molecular Dynamics Simulation of Estrogen Receptor Alpha Against Andrografolid as Anti Breast Cancer, Indonesian Journal of Pharmaceutical Science and Technology, 6(2), 65-76.

Ekins, S., Mestres, J. and Testa, B., 2007, In silico Pharmacology for Drug Discovery: Methods Fo Virtual Ligand Screening and Profiling, British Journal of Pharmacology, 152, 9-20.

Girault, I., Biece, I. and Lidereau, R., 2006, Role of Estrogen Receptor Alpha Transcriptional Coregulators in Tamoxifen Resistance in Breast Cancer, Maturitas, 54(4), 353-61.

Hardjono, S., 2013, Sintesis dan Uji Aktivitas Antikanker Senyawa 1-(2- Klorobenzoiloksi) urea da 1-(4-klorobenzoiloksi)urea [Synthesis and Test of Anticancer Activity of Compounds 1- (2- Chlorobenzoyloxy) urea and 1- (4-Chlorobenzoyloxy) urea], Berkala Ilmiah Kimia Farmasi [Periodical Scientific Pharmaceutical Chemistry], 2(1), 1-8.

Hayashi, 2003, The Expression and Function of Estrogen Receptor $a$ and $B$ in Human Breast
Cancer and Its Clinical Application, International Congress on Hormonal Steroids and Hormones and Cancer, 10, 193.

Hodge, H.C. and Sterner, J.H., 1949, Tabulation of Toxicity Classes, Journal American Industrial Hygiene Association Quarterly, 10(4), 93-96.

Jordan, V.C., Curpan, R. and Maximov, P.Y., 2015, Estrogen Receptor Mutations Found in Breast Cancer Metastases Integrated With the Molecular Pharmacology of Selective ER Modulators, J. Natl Cancer Inst, 107(6), 1-10.

Kabel, A.M. and Baali, F.H., 2015, Breast Cancer: Insight into Risk Factors, Pathogenesis, Diagnosis, and Management, Journal of Cancer Research and Treatment, 3(2), 28-33.

Katno, S. and Pramono, 2017, Tingkat Manfaat dan Keamanan Tanaman Obatdan Obat Tradisional [Level of Benefits and Safety of Medicinal Plants and Traditional Medicines], Yogyakarta: Universitas Gadjah Mada.

Kusumaningrum, S., Budianto, E., Kosela, S., Sumaryono, W. and Juniarti, F., 2014, The molecular docking of 1,4-naphthoquinone derivatives as inhibitors of Polo-like kinase 1 using Molegro Virtual Docker, Journal of Applied Pharmaceutical Science, 4(11), 047-053.

Leygue, E. and Murphy, L.C., 2013, A bi-faceted role of estrogen receptor beta in breast cancer, Endocr Relat Cancer, 20(3), R127-39.

Listiyana, A., Lestari, N.A., Irawati, S., Indrawijaya, Y.A., Annisa, R., et al., 2019, Anticancer Activities and Metabolite of UPLCQToF-MS/MS Method from Chrysanthemum cinerariifolium (Trev.), J. Islamic Pharm., 4(1), 19-39.

Makiyah, A. and Tresnayanti, S., 2017, Uji Toksisitas Akut yang Diukur dengan Penentuan $\mathrm{LD}_{50}$ Ekstrak Etanol Umbi lles-iles (Amorphophallus variabilis Bl.) pada Tikus Putih Strain Wistar [Acute Toxicity Test Measured by Determination of $\mathrm{LD}_{50}$ Ethanol Extract of Iles-iles Bulbs (Amorphophallus variabilis Bl.) In Wistar Strain White Rats], MKB, 49(3), 145-155.

Médina, P., Favre, G. and Poirot,M., 2004, Multiple 
Targeting by the Antitumor Drug Tamoxifen: A Structure-Activity Study, Curr. Med. Chem, 4(6), 1-18.

Setiawati, A., Riswanto, F.O.D., Yuliani, S.H. and Istyastono, E.P., 2014, Anticancer Activity Of Mangosteen Pericarp Dry Extract Against MCF7 Breast Cancer Cell Line Through Estrogen Receptor -a, Indonesian J.Pharm, 25, 119-124.

Shiau, A.K., Barstad, D., Loria, P.M., Cheng, L., Kushner, P.J., et al., 1998, The Structural Basis of Estrogen Receptor/Coactivator Recognition and The Antagonism of This Interaction by Tamoxifen, Journal cell, 95, 927-937.

Susanti, N.M.P., Saputra1, D.P.D., Hendrayati1, P.L., Parahyangan, I.P.D.N. and Swandari1, I.A.D.G., 2018, Molecular Docking Sianidin dan Peonidin Sebagai Antiinflamasi pada Aterosklerosis Secara In silico [Molecular Docking Cyanidine and Peonidine as Anti-Inflammatory atherosclerosis in silico], Journal of Pharmacy Udayana, 17(1), 28-33.

Thomsen, R. and Christensen, M.H., 2006, Mol Dock:
A New Technique for High-Accuracy Molecular Docking, Journal of Medical Chemistry, 49(11), 3315-3321.

Ukiya, M., Akihisa, T., Tokuda, H. and Suziki, 2002, Constituents of Compositae Plants III Anti-tumor Promoting Effects and Cytotoxic Activity against Human Cancer Cell Lines of Triterpenoid Diols and Triols from Edible Chrysanthemum Flowers, Cancer Letters, 177, 7-12.

World Health Organisation (WHO), 2014, Indonesia,World Health Organisation, http:// www.who.int/_cancer/countryprofiles/idn_ en.pdf?ua=1, accessed on May 24, 2020.

Zein, M.F., Andriani, R. and Damayanti, S., 2016, Analisis In silico Genestein dan Analognya Sebagai Inhibitor Kanker Payudara Reseptor Estrogen Alfa Positif (ERa+) [In silico Genestein Analysis and its Analogs as Positive Cancer Estrogen Estrogen Receptor (ERa+) Breast Cancer], Jurnal Farmasi Galenika (Journal of Pharmacy Galenika), 2(2), 56-65. 